\title{
High Temperature Rheological Characteristics of Iron and Steel Making Slag and its Waste Heat Recovery-A Review
}

\author{
Onuora Okorie* \\ Department of Chemical Engineering, Enugu State University of Science and Technology, \\ Enugu State, Nigeria
}

\begin{abstract}
Rheological analyses of materials are essential/major branch of science and engineering which have received much attention. Their determinations having undergone high melting temperature materials requires specialist equipment to ascertain accurate rheological values during the processes. Although they have been an existed theoretical/semiempirical models obtained from literatures, it is imperative to develop a specific mathematical models of rheological parameters from direct experimental data that best suits the metallurgical material. The environmental sustainability could be further enhanced through the recycle of these wastes into useful new products. This paper reviewed the high temperature rheological characteristics of slags and various methods used in recovery of waste heat during iron and steel making processing. Although chemical methods have been accepted by most researchers to be a better option for waste heat recovery, however, there is need for complex and multi-step technologies so as to obtain meaningful energy and material recoveries.
\end{abstract}

\section{Keywords}

Rheology, Iron and steel making slag, High temperature, Gas emission, Waste heat recovery

\section{Introduction}

Iron and steel making practice today is extremely complex in view of the optimization of the various unit processes with respect to the chemistry of the process, the technological aspect, process economy as well as environmental considerations. This industry is one of the most energy and $\mathrm{CO}_{2}$-intensive industries [1-16] consuming around 9\% of total anthropogenic energy $[17,18]$ and accounts for about $20 \%$ of annual industrial energy utilization [11].

The metallurgical processes generate significant pollutant and greenhouse gas emissions, thereby causing serious environmental challenges [7,19-25]. Riley, et al. [26] estimated the $\mathrm{CO}_{2}$ emissions/t steel for various countries. They included $\mathrm{CO}_{2}$ emissions from electricity generation, using factors of $0.95 \mathrm{~kg} / \mathrm{kWh}, 0.87 \mathrm{~kg} / \mathrm{kWh}$ and $0.6 \mathrm{~kg} / \mathrm{kWh}$ for coal, oil and natural gas-based power generation, respectively. Despite the differences on how iron, steel and electricity are produced in each of these countries, blast furnace iron making is the predominant source of steel mill $\mathrm{CO}_{2}$. Iron and steel sector releases $7 \%$ of the total $\mathrm{CO}_{2}$ emission [27-30] and $16 \%$ of the total industrial emission of $\mathrm{CO}_{2}$ globally [31-33]. In Nigeria, this industry is endowed with all major raw materials needed for its production including over 3 billion metric tons of iron ore deposits [34,35] 3 billion tons of coal [36], limestone in excess of 700 million tons and 187billion SCF of natural gas [37]. Although numerous advanced iron and steel making technologies have been implemented, the industry still faces a serious challenge of meeting the $\mathrm{CO}_{2}$ targets when global emissions are cut to less than $50 \%$ of 2000 levels by $2050[38,39]$. Nevertheless, with the greenhouse gases (GHG) footprint, the material flows of this industry have been mapped by several studies [40-42], and researches on best way to utilize this $\mathrm{CO}_{2}$ are currently on top gear. Iron and steel manufacturing industry has been capturing $\mathrm{CO}_{2}$ from its flue gas with carbon-trapping technologies (e.g: Amine scrubbing, electrostatic precipitator) and recycling their waste products within the plant itself to limit excess handling and transportation of waste to disposal facilities [28].

The iron ore when exposed to high temperature using coal gasification happens to envelop different impurities and some of them like aluminium (Al), are the main structural constituents; while some, such as nickel, zinc and copper

*Corresponding author: Onuora Okorie, Department of Chemical Engineering, Enugu State University of Science and Technology, Enugu State, Nigeria, Tel: +2348032740685

Accepted: November 16, 2020

Published online: November 18, 2020

Citation: Okorie O (2020) High Temperature Rheological Characteristics of Iron and Steel Making Slag and its Waste Heat Recovery-A Review. Adv Metallurg Mater Eng 3(1):104-116 
are part of the traced element fraction $[43,44]$. Sviridova, et al. [45] reported that a more intense extraction of iron will contribute to an increase in the temperature of the process, when conducting thermodynamics analysis. They also reported that the longer the slag melt is kept and the higher the temperature in the range $1300-1650^{\circ} \mathrm{C}$, the higher is the degree of metal recovery. Chen, et al. [46] investigated the thermodynamics properties for reduction of iron oxide ore particles in a high temperature drop tube furnace. They reported that at high temperatures (>1660 K), the reaction of ore particle consists of the thermal decomposition and topo chemical reduction by the reducing gas. They also reported that the reduction degree of the ore does not increase obviously with the increase of temperature.

\section{Iron and Steel Making Wastes and its Useful- ness}

During the iron, steel making and refining processes, several by-products such as slags ( $90 \%$ by mass), process gases, ducts, mill-scales and sludges are generated as metallurgical wastes [47-49]. Metallurgical slags constitute the largest by-product of the high temperature operations involved in the extraction and refining of metals whereas the dust and sludge removed from the gases consist primarily of iron and can mostly be used again in steelmaking. With increasing capacities, disposal of these large quantities of slag becomes a big environmental concern and a critical issue for iron and steelmakers [48]. This excessive slag could be classified as blast furnace slag and steelmaking slag. The blast furnace slag (BFS) depends on the speed of cooling which could be further categorized either as granulated slag (GBS), air-cooled slag (ABS), pelletized slag and expanded slag [50], whereas the steelmaking slag consists of basic oxygen furnace slag (BOFS), electric arc furnace slag (EAFS) and ladle furnace slag (LFS) [21,51-54]. This is summarized as shown in Figure 1 [54]. Granulated blast furnace slag is produced by quenching molten furnace slag with high-pressurized water. Blast furnace slags cooled in air constitute a crystallized material used as raw material instead of sand in the production of concrete. Blast furnace slag is obtained at high temperature and its viscosity is around 0.4-1.0 poise [55]. The largest is the output of blast furnace slag- per 1 ton of pig iron, which is $0.5-0.7$ tons, while the smallest- when smelting steel in electric arc furnace is $0.1-0.4$ tons.

During metal extraction, the rheological properties of the system change due to the transition from a one-phase liquid to a multi-phase suspension and the changing chemical composition of the slag. In iron making process, the metallurgical properties of blast furnace slags are determined largely by its viscosity hence high-temperature viscosity measurement is practically difficult, time-and-cost consuming. During the blast furnace operations, some solid phases such as oxide precipitates, coke or $\mathrm{Ti}(\mathrm{CN})$ can be present in the slag. In addition, the precipitation of solid particles was commonly observed in iron, steel, copper and other pyrometallurgy process. These solids can significantly increase the viscosity

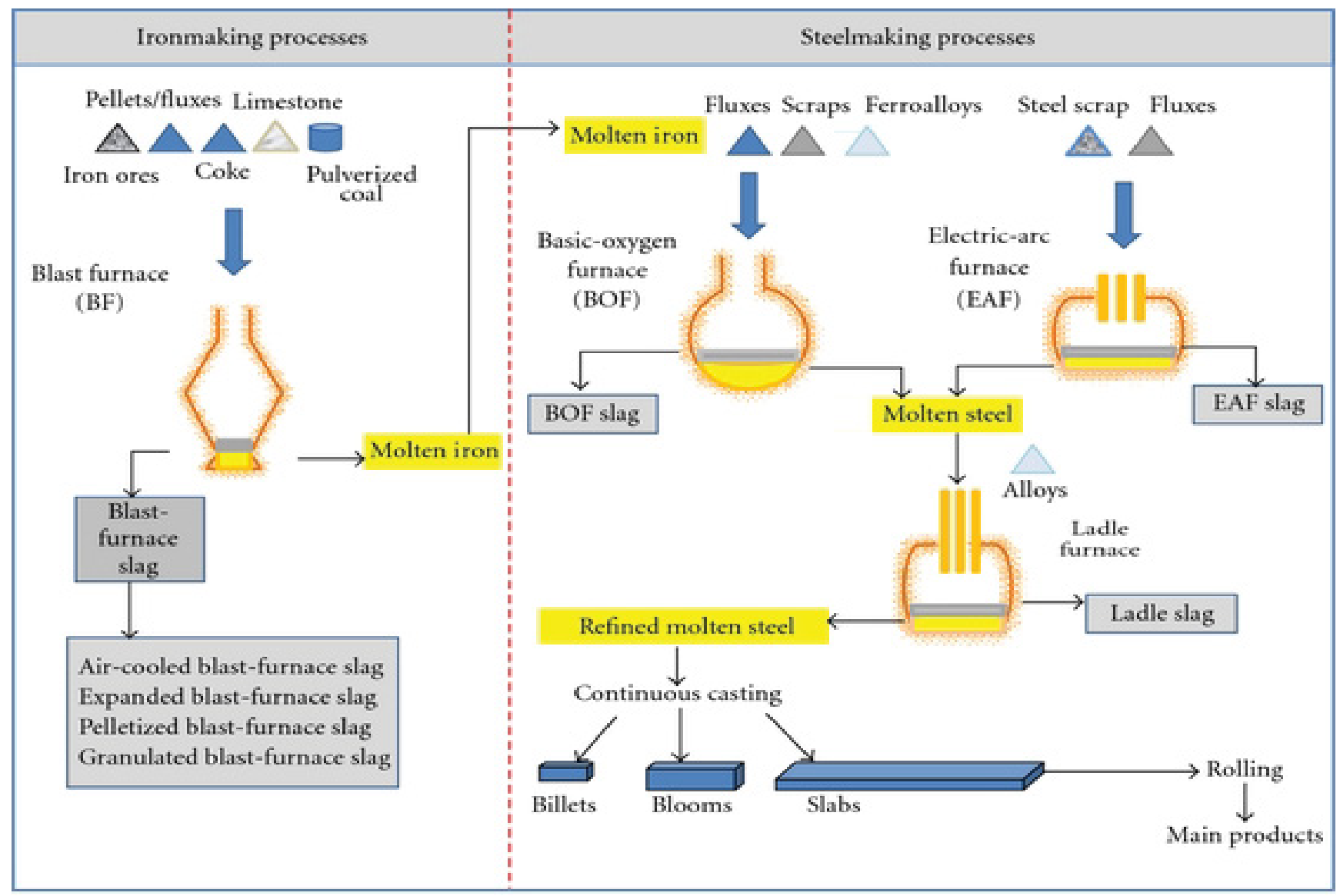

Figure 1: Flow diagram of iron and steel making processes [54]. 
Citation: Okorie O (2020) High Temperature Rheological Characteristics of Iron and Steel Making Slag and its Waste Heat Recovery-A Review. Adv Metallurg Mater Eng 3(1):104-116

Table 1: Chemical composition of iron and steel slag (wt. \%) [63].

\begin{tabular}{|l|l|l|l|l|l|l|l|l|l|l|l|}
\hline $\begin{array}{l}\text { Furnace } \\
\text { Type }\end{array}$ & $\mathrm{CaO}$ & $\mathrm{SiO}_{2}$ & $\mathrm{Al}_{2} \mathrm{O}_{3}$ & $\mathrm{MgO}$ & $\mathrm{MnO}$ & $\mathrm{TiO}_{2}$ & $\mathrm{FeO}$ & $\mathrm{P}_{2} \mathrm{O}_{5}$ & $\mathrm{Cr}_{2} \mathrm{O}_{3}$ & $\mathrm{Fe}_{2} \mathrm{O}_{3}$ \\
\hline BFS & $30-56$ & $28-38$ & $8-24$ & $1-18$ & $0.5-2$ & na & $0.5-1$ & na & na & na \\
\hline BOFS & $30-55$ & $8-20$ & $1-6$ & $5-15$ & $2-8$ & $0.4-2$ & $10-35$ & $\leq 2$ & $\leq 0.73$ & na \\
\hline EAFS & $30-50$ & $11-20$ & $10-18$ & $8-13$ & $5-10$ & na & $8-22$ & $2-5$ & na & $5-6$ \\
\hline LFS & $30-60$ & $2-35$ & $5-35$ & $1-10$ & $0-5$ & na & $0.1-1.5$ & $\leq 0.9$ & $\leq 0.73$ & na \\
\hline
\end{tabular}

of the slag causing operating difficulty. Among various types of steel slags, basic oxygen furnace and electric arc furnace slags are the major by-products worldwide in terms of annual production quantities [56]. Slag has a specific heat capacity of $810 \mathrm{~kJ} / \mathrm{kg} \cdot \mathrm{K}$. The bulk density of steel slag lies between 3.3-3.6 $\mathrm{g} / \mathrm{cm}^{3}$, with water content of $3 \% \sim 8 \%$ [57]. In appearance, steel slag appears hard and wear-resistant due to its high Fe content. Slags are porous and have large surface area with suitable hydraulic conductivity $[53,58]$. According to previous studies, about $70 \%$ of the total production of blast furnace slag has been used as a replacement for Portland cement due to its numerous advantages, e.g., an increase in long-term strength and durability, decreased heat of hydration and the occurrence of the alkali-aggregate reaction. Only $1 \%$ of steelmaking slag has been used as an admixture because steelmaking slag has relatively low hydraulicity and has a problem with volumetric expansion [59]. The grind ability index of steel slag is 0.7 , in contrast with the value of 0.96 and 1.0 for blast furnace slag and standard sand respectively $[60,61]$. The chemical component of iron and steel slag varies with the furnace type, its grades and pretreatment method. Table 1 [62] summarizes the chemical composition at different furnace slag.

Over 400 million tons of iron and steel slag worldwide are produced each year [47,51]. In 2019, world iron slag production was estimated to be between 320 million to 384 million tons, with steel slag production estimated to be between 190 million to 280 million tons. Quantities of iron ore type and ash of coke determines the variation of the different slags and its properties [63-68]. The cooling process of slag is the main reason for generation of different types of slag's required for various purposes. This slag has a worldwide average recovery rate from over $80 \%$ (steelmaking slag) to nearly $100 \%$ (iron making slag) [47] and could be well utilized in many industrial productions such as in building materials-cementitious material processing $[30,52,54,56,57,65,69-86]$; glass ceramic production [83,87-90]; fertilizer [57,65,91-94]; paint [47]; road construction [61,95-102]; water treatment [103,104]. Chemical composition of blast furnace slag has a significant factor in the potential performance of granulated material in cementitious uses. For chemical uses, such as a raw material for manufacture of glass or mineral wool insulation and for agricultural applications, the chemical composition is quite important. It is fortunate, therefore, that the range of slag compositions associated with good iron production is all useful construction materials, although varying in physical properties. The slag composition is also known to have adverse effects on the microstructure and its thermophysical properties, which causes inappropriate cooling of the slag to become weak thus restricting the reuse of slag in other industries $[82,105,106]$.

Research advancement in the slag properties area have been examined over the years, which includes the cooling process $[65,66,82,105,107-112]$ crushing and magnetic separation; basicity [113]; eutectic point [114] energy efficiency $[82,115]$; viscosity [116-123]; melting point [106,122,124130].

Rheology described as a branch of science that have evolved from branch of physics, deals with deformation and flow of matter, has played a significant role in the analyses of iron and steel making slag characteristics [131,132]. The rheological behavior of any material is found to be between two limiting, ideal cases: The ideal solid body (Hookean body), which shows deformation proportional to the stress, and the ideal viscous material (Newtonian body), which shows rate of deformation proportional to the stress [133]. This has generated a relationships between stresses, strains, shear rates and time at which the slag has undergone to such a strain [116]. The viscosity of slag is distinctly dependent on the temperature and structure of the fluid. Many liquids, including most liquid synthetic and industrial slags, have shown a dependency of viscosity on the temperature in accordance with the standard Arrhenius-Guzman energy equation [134-137], given by the expression:

$$
\log \eta=A+\frac{E}{T}
$$

Where $\eta$ is viscosity, $\boldsymbol{T}$ is temperature, $\boldsymbol{A}$ is fitting parameter and $\boldsymbol{E}$ represents the activation energy. Sridhar, et al. [138] reported that viscosities of molten metals and slags play vital roles in many high temperature phenomena that are important for advancing process control and product quality in molten-metal processing and casting. He stated that the need exists for reliable viscosity estimation methods based on the temperature and composition of the melt because measuring viscosities of high-temperature melts is expensive. Viscous flow in slag depends on the mobility of ionic species in the system, which in turn depends upon the nature of the chemical bond and the configuration of ionic species $[139,140]$.

Rheological determination when heated at high temperature requires advanced specialist equipment which allows obtaining the high temperature readings inside during metallurgical processing of the material easier and also professional experienced personnel that can interpret the data obtained [116]. Experimental tests of physical properties as viscosity and surface tension of multi component systems at high temperatures (higher than $1500^{\circ} \mathrm{C}$ ) are difficult to carry out due to the complexity of the process and the amount of time in- 
volved. Thakur and Sarkar [141] reported that some magnetorheological (MR) devices reached high temperatures during operation and its strength gets affected as the temperature increases. The main task of rheology is to develop models to describe the behaviours of bodies that have been subjected to a force impact and several researchers have already carried out studies in this area using high temperature rheometer, also known as multipoint absolute viscometer to analyse both Newtonian and non-Newtonian fluids [116,142-145]. So far, measurement of rheological parameters, which includes the dynamics of the arc's influence on the properties of liquid steel and slag, dynamics of the influence of a reduction gas on liquid slag and pig iron in the blast furnace, the phenomena involving the move of semi-liquid and liquid products down the blast furnace in counter-flow with the reduction gas and then their flow down between the pieces of coke, are extremely difficult in its actual metallurgical processes [146]. It is also observed that the precision of temperature measurements is another major problem encountered during the metallurgical processing, of which the sample temperature is determined on the basis of temperature measurement conducted in the furnace [122]. Most numerical rheological models used in dynamic viscosity coefficient calculations of non-newtonian fluids largely depend on thermodynamic characteristics, which are gotten from the literature $[117,147,148]$, however, there is urgent need to develop rheological models from experimental data suitable for iron and steel making processes.

Seok, et al. [149] reported that slag viscosities increase with decreasing temperature for almost all the slags that was investigated over a range of temperature range, and the slag viscosity exhibited different behavior in the temperature range lower and higher than $1773 \mathrm{~K}$. They also reported that viscosity of the present slag systems decreased with increasing $\mathrm{FeO}$ content. Song, et al. [150] investigated the rheological behavior of slag experimentally using a high-temperature rheometer at temperature between $1200^{\circ} \mathrm{C}$ and $1340{ }^{\circ} \mathrm{C}$ and correlated with the aid of computer software package Fact Sage. They result showed that the sensitivity of the slag viscosity to temperature decreases with increasing rotation speed. Jiang, et al. [151] carried out an experiment on the rheological properties of a blast furnace slag system using a high-temperature rheometer to reveal the non-Newtonian behavior of molten slag. They observed that molten slag exhibited the Newtonian fluid behavior when the temperature was higher than the critical viscosity temperature of the molten slag. In contrast, the molten slag exhibited the non-Newtonian pseudo plastic fluid characteristics and shear thinning behavior at temperature less than the critical viscosity temperature of the molten slag. Migas and Slezak [152] performed an analysis of high temperatures rheometry measurements. They observed at high temperatures, titanium oxide $\left(\mathrm{TiO}_{2}\right)$ may be reduced from the slag-liquid phase with the crucible carbon and titanium carbonitrides may precipitate and at lower temperatures, the perovskite phase may precipitate (apart from the existing high-melting solid particles). Wang, et al. [153] revealed the influence of basicity and $\mathrm{MgO} / \mathrm{Al}_{2} \mathrm{O}_{3}$ ratio on the viscous behavior of $\mathrm{CaO}-\mathrm{SiO}_{2}-\mathrm{Al}_{2} \mathrm{O}_{3}-\mathrm{MgO}-\mathrm{CaCl}_{2}$ slags under conditions of $\mathrm{C} / \mathrm{S}=0.90-1.30$ and $\mathrm{MgO} / \mathrm{Al}_{2} \mathrm{O}_{3}=0.40-0.67$. They indicated that the $\mathrm{MgO} / \mathrm{Al}_{2} \mathrm{O}_{3}$ ratio almost has no influ- ence on the viscosity of the chlorine-containing slags at higher temperatures. Liu, et al. [139] investigated the effect of $\mathrm{Al}_{2} \mathrm{O}_{3}$ content on viscosity, and observed that the viscosity of blast furnace slag exhibits a constant declining trend as temperature increases and a turning point occurs in the viscosity-temperature curves under different $\mathrm{Al}_{2} \mathrm{O}_{3}$ contents. Jiao, et al. studied the effect of $\mathrm{Al}_{2} \mathrm{O}_{3}$ contents on the viscosity of $\mathrm{SiO}_{2}-\mathrm{CaO}-\mathrm{MgO}-\mathrm{Al}_{2} \mathrm{O}_{3}-\mathrm{FeO}$ slag system at a fixed basicity of 1.3 as a function of temperature. They observed that increase in temperature smoothly decreases the viscosity in the fully liquid region and also, the slag viscosity increases rapidly as the temperature increases to a specific value. They also reported that influence of $\mathrm{Al}_{2} \mathrm{O}_{3}$ on the slag viscosity in different $\mathrm{MgO}$ content is too complex to distinguish easily. Shen, et al. [154] reported that when the temperature of the slag is lower than the liquid us temperature, the quantity and type of the phase has a significant influence on the slag system; and when the temperature is higher than the liquid us temperature of the slag, the viscosity of the slag system is mainly affected by the slag structure.

A total number of 2958 viscosity measurements from 582 compositions in the $\mathrm{SiO}_{2}-\mathrm{Al}_{2} \mathrm{O}_{3}-\mathrm{CaO}-\mathrm{MgO}$ system have been collected from 34 publications and these data have been critically reviewed for developing a viscosity model for iron and steelmaking slags $[113,138,149,150,155-183]$. lida, et al. [178] measured the viscosity experimentally and validated the results of different models for different slag systems at various temperatures.

\section{Iron and Steel Waste Heat Recovery}

With the growing trend of increases in fuel prices over the past decades as well the rising concern regarding global warming, iron and steel industries are challenged with the task of reducing greenhouse gas emissions, saving energy and improving the energy efficiency of their sites [184]. In this regard, the use of waste heat recovery systems in iron and steel making processes has been key as one of the major areas of research to reduce fuel consumption, lower harmful emissions and improve production efficiency [47,185-193]. There are many types of waste heat energy in the process of iron and steel making and the amount of waste heat is relatively large $[12,17,82,194]$. This waste heat is mainly in blast furnace slag sensible heat, hot blast furnace cooling water, blast furnace gas sensible heat, hot air stove flue gas sensible heat and from the steelmaking processing units [195]. Approximately 0.3 tons of blast furnace slags (BFS) are produced for each ton of steel manufactured. This BFS came out at above $1773 \mathrm{~K}$ and each ton carried about $1.77 \mathrm{GJ}$ of energy [196]. Consequently, about 235 million tons of BFS were produced with energy content of $4.16 \times 10^{8} \mathrm{GJ}$, which was converted into 14.20 million tons standard coal [5]. Therefore, it was of great significance to recover and utilize the high quality waste heat of molten BFS for iron and steel industry [4,197].

Waste heat is an invisible energy resource and can be categorized as follows according to the temperature: high temperature waste heat (above $650{ }^{\circ} \mathrm{C}$ ), medium temperature waste heat $\left(230-650{ }^{\circ} \mathrm{C}\right)$ and low temperature waste heat (below $230^{\circ} \mathrm{C}$ ), which are 3.36, 2.19 and $2.89 \mathrm{GJ} / \mathrm{t}$ steel 
respectively, equivalent to $287 \mathrm{kgce} / \mathrm{t}$ steel totally [8]. Current heat recovery solutions focus just on high and medium temperature waste heat because no opportunity to exploit low temperature waste heat exists within the iron and steel making plant. It is worth noting that low temperature waste heat currently represents a cost for the steel industry which must spend further energy to dissipate it. While low temperature waste heat has less thermal and economic value than high temperature heat, it is ubiquitous and available in large quantities. Hence, new technologies are developing that may provide significant opportunities for low temperature heat recovery. Waste heat can be rejected at any temperature; conventionally, the higher the temperature, the higher the quality of the waste heat and the easier optimization of the waste heat recovery process [189]. Key factors in determining the waste heat recovery feasibility includes: Heat quantity, heat temperature/quality, waste stream composition, minimum allowed temperature and operating schedules, availability. It is therefore important to discover the maximum amount of recoverable heat of the highest potential from a process and to ensure the achievement of the maximum efficiency from a waste heat recovery system. The recovery ratio of the high quality energy was less than $2 \%$ because of the basic constraints, i.e., low thermal conductivity-hindering heat extraction rate at sufficient rates, high crystallization tendency and discontinuous availability $[12,17,96,198-201]$.

Waste energy recovery from iron and steel slag is difficult as heat removal results in a phase change from liquid to solid state. The formation of this solid slag on the surface of cooling slag inhibits heat transfer and solidification of the slag prevents circulation or movement of slag through heat exchangers and heat transfer devices. The use of slag product depends to a great extent on its mineragraphy, which is closely related to heat transfer and crystallization during the continuous cooling process [202]. In China, the molten steel slag temperature discharged in steelmaking process contains heat about $2000 \mathrm{MJ} / \mathrm{t}$ up to $1450 \sim 1650{ }^{\circ} \mathrm{C}$, equivalent to $61 \mathrm{~kg}$ standard coals, belong to high-quality residual heat resources, great value of exploiting and utilizing. The thermal energy contained in the slag is equivalent to the energy in 12.3 million tons of coal equivalent [203]. Water quenching has been a traditional heat recovery technology which uses cold water to cool down slag but this technology consumes a huge amount of water and fails to recover the sensible heat energy of molten slag which is about $1.77 \mathrm{GJ} /$ ton $[82,124,204,205]$.

Generally, extensive traditional and advanced methods have been exploited and investigated to extract the waste heat of high-temperature slags, which can be classified into physical methods, chemical methods, thermal methods and direct electricity generation methods [95]. Heat energy of slag can also be recovered by both physical and chemical methods. Regarding the physical methods such as mechanical crushing, air blast and centrifugal granulating process, etc. are widely investigated. With respect to chemical methods, methane reforming reaction, biomass gasification and coal gasification process have been proposed $[4,63,206-211]$. As a traditional method, physical methods concentrate on the development of various granulation technologies through which the molten slags was granulated into small particles (GBFS) and the thermal heat in the slags exchanged with a heat transfer medium (air, steam, and phase-change materials (PCM)). Kasai, et al. [211], Shimada, et al. [212,213] and Mizuochi, et al. [214] suggested a dry granulation process without water quenching. When compared to water quenching, dry cooling method not only offered the basis for heat recovery from molten slag but also has the advantages of water conservation and no drying costs for slag utilization. Although physical methods were gradually reaching commercial testing and acceptance, they had obvious disadvantages which could be attributed to the fundamental constraints of heat recovery [17]. On the other hand, heat recovery through chemical methods has shown some specific advantages to meet these constraints. During the heat recovery using chemical methods, slags can act as not only heat carriers but also as good catalysts and reactants, which expand the field of utilization of slags $[17,206,215]$. For direct electricity generation methods combined with heat recovery from slags, the thermal energy could be exchanged and stored in the phase-change materials (PCM) and utilized for electricity generation using the Seebeck effect $[17,216]$.

Shimizu, et al. [217] investigated heat recovery from molten BF slag using a fluidized bed vessel. In their laboratory-scale prototype, molten slag droplets were fed into a fluidized bed vessel consisting of crushed solid slag. The heat from the resulting phase change was recovered through boiler tubes. There was no direct contact between the BF slag and the boiler tube. Moon, et al. [218] reported that dry granulation processes based on air blast, rotating drums or spinning cup, recovers $\sim 40 \sim 60 \%$ of the slag heat in the form of hot air at a temperature over $600^{\circ} \mathrm{C}$. The hot air could be used for steam generation or other on-site uses. Zhao, et al. [219] carried out feasibility of municipal solid waste (MSW) gasification using hot slag explored at 873-1173 $\mathrm{K}$ and it was found that the BFS acted as a catalyst \& heat carrier which promoted the gasification reactivity of MSW. Chan, et al. [220] pointed out that recuperator installation is one of the most effective approaches of energy efficiency in reheating process in steel production; generally, it can achieve $10 \%$ heat recovery for reheat furnace.

Barati, et al. [82] evaluated these three technologies (physical, chemical and direct electricity generation methods) and found that, for both thermal \& chemical energy recovery, a two-step heat recovery process would yield a high efficiency with minimal technical risk. Moreover, based on the inherent crystallization properties of slags $[109,119]$, the heat recovery from slags should be divided into at least three stages. Luo, et al. [210] used biomass steam gasification recovering the waste heat of BF slag to produce syn gas. They made use of a moving-bed reactor and the results showed that BFS demonstrated good catalytic performance in improving tar cracking, enhancing char gasification and reforming of hydrocarbons; higher BFS temperature and smaller particles size can produce more light gases, less char and condensate. Using a similar experimental system, biomass pyrolys is using hot slags for bio-oil production was investigated at 773-1023 K [221]. It was found that an increase in slag particle size and biomass 
particle size decreased the production of bio-oil because of the change of heat transfer between slag particle and biomass particles. Analyzing the characterization of molten BFS waste heat and current energy situation of China. Duan, et al. $[222,223]$ carried on rigorous research of utilizing coal gasification reaction to recover the high temperature and quality waste heat of BFS. Tobo, et al. [200] proposed a unique process of slag waste heat recovery. The sensible heat of the sheet-shaped slag was recovered by a counter-flow packed bed type heat exchanger and showed that the heat recovery ratio is over $30 \%$. Motz, et al. [224] carried out research on dry solidification with heat recovery of ferrous slag. They reported that the waste heat of liquid slag during solidification in the range between more than 1600 and $1000^{\circ} \mathrm{C}$ should be used to generate hot air, steam or electricity. Shachit, et al. [225] employed gas-solid indirect or direct contactor such as packed-bed, moving bed and fluidized bed contactor to recover heat from the dry slag granules. Liu, et al. [226] reported that in many dry granulation technologies, high temperature molten slag is atomized to slag particles and the thermal energy from high temperature slag particles are recovered by physical and chemical methods. They exploited gravity-bed waste heat boiler for thermal energy recovery from high-temperature slag particles and observed that an increase in Reynolds number (Re) showed no effect on the heat transfer coefficient or recovery efficiency. However, the heat transfer coefficient and recovery efficiency increased with a decrease in particle diameter and an increase in the velocity of descending particles. Yu, et al. [188] reviewed the granulation process for blast furnace slag. They reported that for every pig iron production accompanied by 0.3-0.6 tons of blast furnace slag produced with the temperature of $1350-1450^{\circ} \mathrm{C}, 1600-1800$ MJ sensible heat equivalent to 55-61 kg standard coal combustion after the heat generated. After thorough comparative analysis of water quenching and dry granulation processes, they concluded that centrifugal granulation affiliated with dry granulation was the optimum process, having smaller slag particle size (about $2 \mathrm{~mm}$ ), more glassy phase and higher recovery rate. Liu, et al. [203] investigated waste heat recovery from high temperature blast furnace slag particles. A heat transfer models for packed bed, moving bed and fluidized bed to recover thermal energy from high temperature slag particles were established. Their results showed that the packed bed, moving bed and fluidized bed were not suitable for recycling thermal energy from slag particles with small diameter, high temperature and flowrate. Based on this problem encountered, they exploited a technique of thermal energy recovery from high temperature slag particles using gravity bed waste heat boiler to produce steam. Its heat recovery rate reached as much as 91\%. Deng, et al. [227] studied air-cooling waste heat recovery from molten slag of slag-tap boilers. They reported that thermal efficiency of the boiler increased resulting in a decrease of fuel consumption rate. Renuka, et al. [228] suggested a suitable method for heat recovery from blast furnace slag in a steel industry using a suitable phase change material. The system used allowed capture of waste heat energy and was employable for generating power without using nonrenewable sources like coal, gas, etc. Zhang, et al. [8] examined various waste energy recovery technology, such as coke dry quenching (CDQ), combined cycle power plant (CCPP), waste energy recovery from Linz-Donawitz process, etc, which have been used widely and contributed a lot to the energy savings. They introduced two typical processes under development- vertical tank cooling system for sinter sensible heat recovery and the Organic Rankine Cycle (ORC) system used in recovering the waste heat from blast furnace slag quenching water for power generation. $\mathrm{Li}$, et al. [229] investigated the thermodynamics analysis of waste heat recovery system using different methods to recover the sensible heat of molten BF slag. The results showed that the heat efficiency of physical methods was $76.9 \%$, and the energy efficiency of recovery as steam was $34.2 \%$, the heat efficiency of combined methods was $92.2 \%$, and the exergy efficiency is above $60 \%$. This signifies that heat efficiency and energy efficiency of combined methods were higher than that of physical methods.

Zhan, et al. [230] developed a new process for generating hydrogen-enriched syn gas by the coal gasification using molten BFS as heat carrier. Their result showed that the main gas components in the molten pool were steam, $\mathrm{H}_{2}, \mathrm{CO}$ and $\mathrm{CO}_{2}$. Duan, et al. $[4,222,223,231]$ carried out an extensive research of utilizing coal gasification reaction in order to recover the high temperature and quality waste heat of blast furnace slag. Duan, et al. [231] proposed the multi-stage slag waste heat recovery system. They evaluated the proposed system in comparison with convectional water quenching method-open circuit process and latest dry slag granulation method and found out that proposed system has a good application potential in the aspect of energy conservation and emission reduction for iron and steel industry. Duan, et al. [5] also proposed a novel method of heat recovery system from blast furnace slag with coal gasification reaction to generate syn gas. Their result suggested that the optimal conditions for slag waste heat recovery were achieved at $1623 \mathrm{~K}$ and steam to coal ratio of 2. Sun, et al. [232] investigated biomass gasification using the waste heat from high temperature (1450$1650^{\circ} \mathrm{C}$ ) slags in a mixture of $\mathrm{CO}_{2}$ and $\mathrm{H}_{2} \mathrm{O}$. Yao, et al. [198] proposed tar steam reforming recovering waste heat of $\mathrm{BF}$ slag and observed it was feasible. Zhang, et al. [233] and Kasai, et al. [211] have proved that it was feasible using chemical methods to recover the waste heat of hot slag. $\mathrm{Wu}$, et al. [234] carried out analysis on the energy recovery of furnace slag from steel industrial and thermo chemical conversion of lingo cellulosic biomass. They reported that combination of biomass pyrolys is with heat recovery from molten slag is a feasible and economically applicable technology. Barati and Jahanshahi [95] investigated granulation and heat recovery from metallurgical slags. They reported that metallurgical slags carries a thermal energy equivalent to $40 \mathrm{Mt} /$ year of coal and the slag-processing technologies are slowly converging around dry granulation combined with heat recovery.

However, Sun, et al. [20] summarized the various energy-saving technologies, energy flow types and energy saving potentials for iron and steel industry.

\section{Conclusion}

Understanding and controlling the behavior of the slag 
phase is crucial in improving the operational and economical efficiencies. High temperature rheological investigations of iron and steelmaking slags have been seen as a necessity during its processing. Most researchers have carried out extensive studies on this subject matter and its usefulness is unquantifiable. There is a large potential to reduce, reuse and utilize the energy consumption in the iron and steel industry through heat recovery from hot slags. Many methods have been exploited to extract this waste heat from slag. The chemical methods offer better production from slag heat but still face fundamental constraints and require complex, multistep technologies to yield meaningful energy and material recoveries.

\section{References}

1. He H, Guan H, Zhu X, et al. (2017) Assessment on the energy flow and carbon emissions of integrated steelmaking plants. Energy Reports 3: 29-36.

2. He K, Wang L, Li X (2020) Review of the energy consumption and production structure of China's steel industry: Current situation and future development. Metals 10: 1-18.

3. Duan W, Yu Q, Wang Z, et al. (2018a) Flow characteristic of twophase bubble reactor for slag waste heat recovery. The Minerials, Metals \& Materials Society 111-119.

4. Duan WJ, Gao YK, Yu QB, et al. (2019a) Numerical simulation of coal gasification in molten slag: Gas-liquid interaction characteristic. Energ. 183: 1233-1243.

5. Duan W, Gao Y, Yu Q, et al. (2019b) Combining theory and experiment analysis in molten BFS waste heat recovery integrated with coal gasification. E3S Web of Conferences 118: 1-5.

6. Elsayed M (2019) Modern blast furnace ironmaking technology: Potentials to meet the demand of high hot metal production and lower energy consumption. Metallurgical \& Materials Engineering 25: 99-104.

7. Tian S, Jiang J, Zhang Z, et al. (2018) Inherent potential of steelmaking to contribute to decarbonisation targets via industrial carbon capture and storage. Nat Commun 9: 1-8.

8. Zhang X, Bai H, Hao J, et al. (2017) Waste energy recovery technology of iron and steel industry in China. Energy Materials. 3-15.

9. Zhang $Q$, Jin $X$, Wang YJ, et al. (2018) Comprehensive assessment of energy conservation and $\mathrm{CO}_{2}$ emissions mitigation in China's iron and steel industry based on dynamic material flows. Appl. Energ 209: 251-265.

10. Otto A, Robinius M, Grube T, et al. (2017) Power-to-steel: Reducing $\mathrm{CO}_{2}$ through the integration of renewable energy and hydrogen into the German steel industry. Energies 10: 1-21.

11. Mousa E, Wang C, Riesbeck J, et al. (2016) Biomass applications in iron and steel industry: an overview of challenges and opportunities. Renewable and Sustainable Energy Reviews 65:12471266.

12. Sun $Y$, Zhang $Z$ (2016) Heat recovery from high temperature slags: Chemical methods. Energy Technology 41-48.

13. Quadera M, Ahmed S, Ghazillaa R, et al. (2015) A comprehensive review on energy efficient $\mathrm{CO}_{2}$ breakthrough technologies for sustainable green iron and steel manufacturing. Renew Sustain Energy Rev 50: 594-614.

14. Sarker T, Corradetti R, Zahan M (2013) Energy sources and car- bon emissions in the iron and steel industry sector in South Asia. International Journal of Energy Economics \& Policy 3: 30-42.

15. Xu CC, Cang D (2010) A brief overview of low $\mathrm{CO}_{2}$ emission technologies for iron and steel making. Journal of Iron and Steel Research International 17: 1-7.

16. Manning CP, Fruehan RJ (2001) Emerging technologies for iron and steelmaking. JOM 53: 20-23.

17. Sun Y, Sridhar S, Liu L, et al. (2015a) Integration of coal gasification and waste heat recovery from high temperature steel slags: An Emerging strategy to emission reduction. Scientific Reports.

18. Allwood JM, Cullen M, Milford R.L (2010) Options for achieving a $50 \%$ cut in industrial carbon emissions by 2050 . Environ Sci Technol 44: 1888-1894.

19. Sun W, Zhou Y, Lv J, et al. (2019) Assessment of multi-air emissions: Case of particulate matter (dust), $\mathrm{SO}_{2}, \mathrm{NO}_{x}$ and $\mathrm{CO}_{2}$ from iron and steel industry of China. Journal of Cleaner Production, 232: 350-358.

20. Sun W, Wang Q, Zhou Y, et al. (2020) Material and energy flows of the iron and steel industry: Status quo, challenges and perspectives. Applied Energy.

21. Omale SO, Choong TSY, Abdullah LC, et al. (2018) Utilization of Malaysia EAF slags for effective application in direct aqueous sequestration of carbon dioxide under ambient temperature. Heligon 5: e02602.

22. Li H, Tan X, Guo J, et al. (2019) Study on an implementation scheme of synergistic emission reduction of $\mathrm{CO}_{2}$ and air pollutants in China's steel industry. Sustainability 11: 1-22.

23. Kan T, Evans T, Strezov V, et al. (2015) Risk assessment and control of emissions from ironmaking. Ironmaking and Steelmaking Processes, 321-329.

24. Wu XC, Zhao L, Zhang YX, et al. (2015) Primary air pollutant emissions and future prediction of iron and steel industry in China. Aerosol Air Qual Res 15: 1422-1432.

25. Gao C, Wang D, Zhao B, et al. (2014) Analyzing and forecasting $\mathrm{CO}_{2}$ emission reduction in China's steel industry. Front Earth Sci 9: 105-113.

26. Riley MF, Rosen L, Drnevich R (2009) Mitigating $\mathrm{CO}_{2}$ emissions in the steel industry: A regional approach to a global need. In: AISTech 2009, Proceedings of the iron and steel technology conference, St. Louis, MO, USA, 4-7 May 2009. Association for Iron and Steel Technology (AIST), Warrendale, PA, USA, 1: 89-101.

27. Mousa E, Lundgren M, Okvist LS, et al. (2019) Reduced carbon consumption and $\mathrm{CO}_{2}$ emission at the blast furnace by use of briquettes containing torrefied sawdust. Journal of Sustainable Metallurgy 5: 391-401.

28. Reddy KR, Gopakumar A, Chetri JK (2019) Critical review of applications of iron and steel slags for carbon sequestration and environmental remediation. Reviews in Environmental Science and Bio/Technology 18: 127-152.

29. Ahman M, Olsson O, Vogi V, et al. (2018) Hydrogen Steelmaking for a Low-Carbon Economy: A Joint LU-SEI Working Paper for the HYBRIT Project. Stockholm Environment Institute 1-25.

30. Pan SY, Adhikari R, Chen YH, et al. (2016) Integrated and innovative steel slag utilization for iron reclamation, green material production and $\mathrm{CO}_{2}$ fixation via accelerated carbonation. J Clean Prod 137: 617-631.

31. Bhaskar A, Assadi M, Somehsaraei HN (2020) Decarbonization 
of the Iron and Steel Industry with Direct Reduction of Iron Ore with Green Hydrogen. Energies13: 1-23.

32. Bataille C, Ahman M, Neuhoff K, et al. (2018) A review of technology and policy deep decarbonization pathway options for making energy-intensive industry production consistent with the Paris agreement. J. Clean. Prod 187: 960-973.

33. Ahman M, Nilsson LJ, Johansson B (2017) Global climate policy and deep decarbonization of energy-intensive industries. Clim Policy 17.

34. Bamalli SU, Moumouni A, Chaanda MS (2011) A review of $\mathrm{Ni}-$ gerian metallic minerals for technological development. Natural Resources 2: 87-91.

35. Adebimpe RA, Akande JM (2011) Engineering economy analysis on the production of iron ore in Nigeria. Geomaterials 1: 14-20.

36. Agbu O (2007) The iron and steel industry and nigerian industrialization: Exploring cooperation with Japan. Institute of developing economics, Japan external trade organization

37. Ohimain El (2010) Emerging bio-ethanol projects in Nigeria: Their opportunities and challenges. Energy Policy 38: 7161-7168.

38. Milford RL, Pauliuk S, Allwood JM, et al. (2013) The roles of energy and material efficiency in meeting steel industry $\mathrm{CO}_{2}$ targets. Environ Sci Technol 47: 3455-3462.

39. Sun $Y$, Zhang Z, Liu L, et al. (2015) Heat recovery from high temperature slags: A review of chemical methods. Energies 8: 19171935.

40. Cullen JM, Allwood JM, Bambach M.D (2012) Mapping the global flow of steel: From steelmaking to end-use goods. Environ Sci Technol 46: 13048-13055.

41. Barati M (2010) Energy intensity and greenhouse gases footprint of metallurgical processes: A continuous steelmaking case study. Energy 35: 3731-3737.

42. Yellishetty M, Ranjith PG, Tharumarajah A (2010) Iron ore and steel production trends and material flows in the world: Is this really sustainable? Resource, Conserv Recycl 54: 1084-1094.

43. Massoudi M, Wang P (2013) Slag behavior in gasifiers. Part II: Constitutive modeling of slag. Energies 6: 807-838.

44. Kan T, Strezov V, Evans T, et al. (2015) Trace element deportment and particle formation behaviour during thermal processing of iron ore: Technical reference for risk assessment of iron ore processing. Journal of Cleaner Production 102: 384-393.

45. Sviridova TV, Bobrova OB, Yu llina O, et al. (2019) Development of steelmaking slag processing scheme for environmental stress reduction. Journal of Physics, 1-6.

46. Chen Z, Qu Y, Zeilstra C, et al. (2020) Thermodynamics evaluation for reduction of iron oxide ore particles in a high temperature drop tube furnace. Ironmaking and Steelmaking 47: 173-177.

47. Branca AT, Colla V, Algermissen D, et al. (2020) Reuse and recycling of by-products in the steel sector: Recent achievements paving the way to circular economy and industrial symbiosis in Europe. Metals 10: 345.

48. Sheridan C M, Dyk LDV, Naidu T (2020) Basic oxygen furnace slag: Review of current and potential uses. Mineral Engineering 149: 106234

49. Elijah IO (2013) Scrap iron and steel recycling in Nigeria, Greener Journal of Environmental Management and Public Safety 2: 1-9.

50. Khushhalpreet S, Gagandeep S, Khushpreet S (2019) Utilization of iron slag as partially replacement with fine aggregate in high strength self-compacting concrete (HSSCC). International Journal of Innovative Technology and Exploring Engineering 8: 11771183.

51. Kumar S, Dhara S, Kumar V, et al. (2019) Recent trends in slag management \& utilization in the steel industry. Mineral \& Metals Review 94-102.

52. Thomas C, Rosales J, Polanco J.A, et al. (2019) Steel slags New Trends in Eco-efficient and Recycled Concrete 169-190.

53. Lim JW, Chew LH, Choong SYT, et al. (2016) Overview of steel slag application and utilization. MATEC Web of Conferences 74: 00026.

54. Yildirim IZ, Prezzi M (2011) Chemical, mineralogical, and morphological properties of steel slag. Advances in Civil Engineering

55. Brandaleze E, Benavidez E, Santini L,(2018) Treatments and recycling of metallurgical slags.

56. Pan SY, Chung TC, Ho CC, et al. (2017) $\mathrm{CO}_{2}$ mineralization and utilization using steel slag for establishing a waste-to-resource supply chain. Scientific Report 7: 17227.

57. Bing L, Biao T, Zhen M, et al. (2019) Physical and Chemical properties of steel slag and utilization technology of steel slag at home and abroad. IOP Conf Ser: Earth Environ. Sci. 242.

58. Alex TC, Kalinkin AM, Nath SK, et al. (2013) Utilization of Zinc slag through geopolymerization: influence of milling atmosphere. International Journal of Mineral Processing 123:102-107.

59. Lee JY, Choi JS, Yuan TF, et al. (2019) Comparing properties of concrete containing electric arc furnace slag and granulated blast furnace slag. Materials 12: 1371.

60. Hou GH, Wang ZH, Zhu X (2010) Difference of grindablity and cementions performance activity among minerals in steel slag. Journal of Yancheng Institute of Technology (Natural Science Edition) 23: 1-4.

61. Yi H, Xu G, Cheng H, et al. (2012) An overview of utilization of steel slag. Procedia Environmental Sciences 16: 791-801.

62. Manchisi J, Matinde E, Rowson NA, et al. (2020) Ironmaking and steelmaking slags as sustainable adsorbents for industrial effluents and wastewater treatment: A critical review of properties, performance, challenges and opportunities. Sustainability 12 : 1-47.

63. Zhang X, Chen J, Jiang J, et al. (2019) The potential utilization of slag generated from iron- and steelmaking industries: A review. Environmental Geochemistry and Health. 42: 1321-1334.

64. Baricova D, Pribulova A, Futas P, et al. (2018) Change of the chemical and mineralogical composition of the slag during oxygen blowing in the oxygen converter process. Metals 8: 844.

65. Horii K, Kitano Y, Tsutsumi N, et al. (2013) Processing and reusing technologies for steelmaking slag. Nippon Steel Technical Report, 123-129.

66. Dippenaar R (2013) Industrial uses of slag (the use and re-use of iron and steelmaking slags) Ironmaking and steelmaking 32: 35-46.

67. Joulazadeh $\mathrm{MH}$, Joulazadeh $\mathrm{F}$ (2010) Slag value added steel industry byproducts. Archives of Metallurgy and Materials 55: 1137-1145.

68. Kang TW, Gupta S, Saha-Chaudhury N, et al. (2005) Wetting and interfacial reaction investigations of coke/slag systems and associated liquid permeability of blast furnaces. ISIJ International 45: 1526-1535. 
69. Micheline MR, Siham KB (2019) Cements made from blast furnace slag. Science Direct Journal 5: 469-507.

70. Nidheesh PV, Kuman MS (2019) An overview of environmental sustainability in cement and steel production. Journal of Cleaner production 231: 856-871.

71. Jiang Y, Ling TC, Shi C, et al. (2018) Characteristics of steel slags and their use in cement and concrete-A review. Resources, Conservation and Recycling 136: 187-197.

72. Wan J, Wu S, Xiao Y, et al. (2018) Study on the effective composition of steel slag for asphalt mixture induction heating purpose. Constr. Build. Mater 178: 542-550.

73. Yuksel i (2017) A review of steel slag usage in construction industry for sustainable development. Environ. Dev. Sustain. 19: 369-384.

74. Morata M, Saborido C, Fontsere V (2016) Slag aggregates for railway track bed layers: Monitoring and maintenance. Proceedings of the 15th International Conference on Railway Engineering Design and Operation. Madrid, UK, 283-294.

75. Roslan NH, Ismail M, Abdul Majid Z, et al. (2016) Performance of steel slag and steel sludge in concrete. Construction and Building Materials 104: 16-24.

76. Qiang W, Mengxiao S, Jun Y (2016) Influence of classified stee slag with particle sizes smaller than $20 \mu \mathrm{m}$ on the properties of cement and concrete. Construction and Building Materials 123: 601-610.

77. Son NK, Phuoc NV, Hanh LTD, et al. (2015) EAF steel slag as supplementary cementing material. Asean Engineering Journal 2: 34-43.

78. Laakri M, Oudjit MN, Abdeli K (2014) Volumetric variation and rheology of cement based mineral additions (Blast furnace slag and silica fume). Journal of Civil Engineering and Architecture 2: 207-212.

79. Baricova D, Pribulová A, Demeter $P$, et al. (2012) Utilizing of the metallurgical slag for production of cementless concrete mixtures. Metalurgija 51: 465-468.

80. Wang Q, Yan P, Mi G (2012) Effect of blended steel slag-GBFS mineral admixture on hydration and strength of cement. Construction and Building Materials 35: 8-14.

81. Gao J, Li S, Zhang Y, et al. (2011) Process of Re-Resourcing of Converter Slag. Journal of Iron and Steel Research International 18: 32-39.

82. Barati M, Esfahani S, Utigard T (2011) Energy recovery from high temperature slags. Energy 36: 5440-5449.

83. Karamanova E, Avdeev G, Karamanov A (2011) Ceramics from blast furnace slag, kaolin and quartz. Journal of the European Ceramic Society 31: 989-998.

84. Hyouk-Seok K, Joo-Won P, Yong-Jun A, et al. (2011) Activation of ground granulated blast furnace slag cement by calcined alunite. Materials Transaction 2: 210-218.

85. Sen T, Mishra U (2010) Usage of industrial waste products in village road construction. International Journal of Environmental Science and Development 1.

86. MonshiF A, Asgarani M.K (1999) Producing Portland cement from iron and steel slag and limestone. Cement and Concrete Research 29: 1373-1377.

87. Teo PT, Abu Seman A, Basu P, et al. (2014) Recycling of Malaysia 's electric arc furnace (EAF) slag waste into heavy-duty green ceramic title. Waste Manag 34: 2697-2708.

88. Wang Z, Ni W, Jia Y, et al. (2010) Crystallization behavior of glass ceramics prepared from the mixture of nickel slag, blast furnace slag and quartz sand. Journal of Non-Crystalline Solids 356: 1554-1558.

89. Francis A (2005) Non-Isothermal Crystallization Kinetics of a Blast Furnace Slag Glass. Journal of the American Ceramic Society 88: 1859-1863.

90. Goto I (2011) Symposium on search for new functions and development of application technology about steelmaking slag in ocean environment. Iron and Steel Institute of Japan, 22.

91. Deng T, Gu H, Qiu R, et al. (2011) Effect of Steel Slag Application on Soil Improvement and Heavy Metal Uptake by Rice. Journal of agricultural and environmental sciences 3: 455-460.

92. Rex M (2005) The use of BF, converter and ladle slags in European agriculture-benefits or risks? Slag-Providing solutions for global construction and other markets. Proceedings of the 4th European Slag Conference, Oulu, Finland, 51-55.

93. Murakami K (2004) Field experiment on use of converter furnace slag to control clubroot disease in broccoli. Japanese Journal of Soil Science and Plant Nutrition, 75: 53-58.

94. Ota M (1964) Study on use of slag for fertilizer. Kazamashobo.

95. Barati M, Jahanshahi S (2020) Granulation and heat recovery from metallurgical slags. Journal of Sustainable Mtallurgy 6: 191206.

96. Xiao Z, Chen M, Wu S, et al. (2019) Moisture susceptibility evaluation of asphalt mixtures containing steel slag powder as filler. Materials 12: 3211.

97. Skaf M, Pasquini E, Revilla-Cuesta V, et al. (2019) Performance and durability of porous asphalt mixtures manufactured exclusively with electric steel slags. Materials 12: 3306.

98. Pasetto M, Baldo N (2018) Re-use of industrial wastes in cement bound mixtures for road construction. Environ Eng Manag J 17: 417-426.

99. Alnadish A, Aman Y (2018) A study on the economic using of steel slag aggregate in asphalt mixtures reinforced by aramid fiber. Arpn J. Eng. Appl. Sci 13: 276-292.

100. Pasetto M, Baliello A, Giacomello G, et al. (2016) Rheological characterization of warm-modified asphalt mastics containing electric arc furnace steel slags. Advances in Materials Science and Engineering 1-11.

101. Grubesa IN, Barisic I, Fucic A, et al. (2016) The Indian experience of steel slag application in civil engineering. Characteristics and uses of steel slag in building construction 141-160.

102. Shen W, Zhou M, Ma W, et al. (2009) Investigation on the application of steel slag-fly ash-phosphogypsum solidified material as road base material. Journal of Hazardous Materials 164: 99-104.

103. Montoya-Bautista CV, Avella E, Ramirez-Zamora, et al. (2019) Metallurgical wastes employed as catalysts and photocatalysts for water treatment: a review. Sustainability 11: 2470.

104. Mercado-Borrayo BM, González-Chávez JL, Ramírez-Zamora RM, et al. (2018) Valorization of metallurgical slag for the treatment of water pollution: An emerging technology for resource conservation and re-utilization. J Sust Metal 4: 50-67. 
105. Liapis I, Papayianni I (2015) Advances in chemical and physical properties of electric arc furnace carbon steel slag by hot stage processing and mineral mixing. Journal of Hazardous Materials 283: 89-97.

106. Kang Y, Lee J, Morita K (2014) Thermal conductivity of molten slags: A review of measurement techniques and discussion based on microstructural analysis. ISIJ International 54: 20082016.

107. Tasaki T, Kudo K, Mukawa S, et al. (2015) Development of a cooling technology for LD-ORP slag at Nagoya works. Nippon Steel and Sumitomo Metal Technical Report 155-159.

108. Crossin E (2015) The greenhouse gas implications of using ground granulated blast furnace slag as a cement substitute. Journal of Cleaner Production 95: 101-108.

109. Sun YQ, Shen HW, Wang H, et al. (2014) Experimental investigation and modeling of cooling processes of high temperature slags. Energy 76: 761-767.

110. Kriskova L, Pontikes $Y$, Pandelaers L, et al. (2013) Effect of high cooling rates on the mineralogy and hydraulic properties of stainless steel slags, Metallurgical and Materials Transactions B 44: 1173-1184.

111. Dippenaar R (2005) Industrial uses of slag (the use and re-use of iron and steelmaking slags), Ironmaking \& Steelmaking 32: 35-46.

112. Tossavainen M, Engstrom F, Yang Q, et al. (2007) Characteristics of steel slag under different cooling conditions. Waste Management 27: 1335-1344.

113. Lee $\mathrm{Y}$, Kim J, Yi S, et al. (2004) Viscous behaviour of $\mathrm{CaO}-\mathrm{SiO}_{2}-$ $\mathrm{Al}_{2} \mathrm{O}_{3}-\mathrm{MgO}-\mathrm{FeO}$ slag. $7^{\text {th }}$ International Conference on Molten Slags Fluxes and Salts, The South African Institute of Mining and Metallurgy.

114. Jak E, Hayes P (2004) Phase equilibria determination in complex slag systems. International Conference on Molten Slags Fluxes and Salts. South African Institute of Mining and Metallurgy.

115. Ramakrishna G, Kadrolkar A, Srikakulapu NG (2015) Exergy and its efficiency calculations in ferrochrome production. Metallurgical and Materials Transactions B 46: 1073-1081.

116. Korolczuk-Hejnak M, Migas P, Slezak W (2015) Determination of the liquid steel viscosity curves using a high temperature rheometer. Journal of Physics: Conference series 602: 7-11.

117. Chen M, Zhang D, Kou M, et al. (2014) Viscosities of Iron Blast Furnace Slags. ISIJ International 54: 2025-2030.

118. Gan L, Lai C (2014) A General Viscosity Model for Molten Blast Furnace Slag. Metallurgical and Materials Transactions B 45: 875-888.

119. Zheng K, Zhang Z, Liu L, et al. (2014) Investigation of the viscosity and structural properties of $\mathrm{CaO}-\mathrm{SiO}_{2}-\mathrm{TiO}_{2}$ slags, Metallurgical and Materials Transactions B 45: 1389-1397.

120. Logachev GN, Gostenin VA, Pishnograev SN, et al. (2013) Mobility of blast-furnace slag. Steel in Translation 43: 805-807.

121. Korolczuk-Hejnak M (2012) Possibilities of applying rheological measurements in metallurgy. Journal of Achievements in Materials and Manufacturing Engineering 55: 541-546.

122. Kim J, Lee $Y$, Min D, et al. (2004) Influence of MgO and $\mathrm{Al}_{2} \mathrm{O}_{3}$ contents on viscosity of blast furnace type slags containing FeO. ISIJ International 44: 1291-1297.
123. Saito N, Hori N, Nakashima K, et al. (2003) Viscosity of blast furnace type slags, Metallurgical and Materials Transactions B 34B: 509-516.

124. Wang H, Wang Y, Cui S, et al. (2019) Reactivity and hydration property of synthetic air quenched slag with different chemical compositions. Materials 12: 932.

125. Guo WT, Xue QG, Liu YL, et al. (2016) Microstructure evolution during softening and melting process in different reduction degrees. Journal of Iron making and Steelmaking 43: 22-30.

126. Wu W, Meng H, Liu L, et al. (2012) Slag melting characteristic of slag forming and slag splashing for BOF less slag smelting. Journal of Iron and Steel Research International 19: 20-25.

127. Dai B, Zhang J (2012) The research of blast furnace slag fluidity by viscosity experiment and phase diagram analysis. Metallurgical International 17: 25-28.

128. Nazari A, Riahi S (2011) The role of $\mathrm{SiO}_{2}$ nanoparticles and ground granulated blast furnace slag admixtures on physical, thermal and mechanical properties of self-compacting concrete. Materials Science and Engineering 528: 2149-2157.

129. Kim H, Kim WH, Sohn I, et al. (2010) The effect of MgO on the viscosity of the $\mathrm{CaO}-\mathrm{SiO}_{2}-20 \mathrm{wt} \% \mathrm{Al}_{2} \mathrm{O}_{3}-\mathrm{MgO}$ slag system. Steel Research International 81: 261-264.

130. Lee YS, Min DJ, Jung SM, et al. (2004) Influence of basicity and FeO content on viscosity of blast furnace type slags containing FeO. ISIJ International 44: 1283-1290.

131. Rehackova L, Dudek R, Rosypalova S, et al. (2016) Comprehensive study of rheological and surface properties of the selected slag system in the context of its internal structure. Metalurgija 55: 697-700.

132. Korolczuk-Hejnak M (2014) Determination of flow curves on selected steel grades in their liquid state. Archive of Metallurgy and Materials 59: 1553-1558.

133. Modigell M, Pola, A, Tocci M (2018) Rheological characterization of semi-solid metals: A Review Metals 8: 245.

134. Yu Z, Leng $H$, Luo $Q$, et al. (2019) Geometrical modeling of the physicochemical properties of $\mathrm{CaO}-\mathrm{Al}_{2} \mathrm{O}_{3}-\mathrm{CaF}_{2}$ slag at $1873 \mathrm{~K}$. Ceramics International 46: 8075-8081.

135. Deng Y, Zhang J, Jiao K (2018) Viscosity Measurement and Prediction Model of Molten Iron. Ironmaking \& Steelmaking 1-5.

136. Gan L, Lai C, Xiong H (2015) Non-Arrhenius Viscosity Models for Molten Silicate Slags with Constant Pre-Exponential Parameter: A Comparison to Arrhenius Model. High Temperature Materials and Processes.

137. Jeyakumar M, Hamed MS, Shankar S (2011) Rheology of liquid metals and alloys. Journal of Non-Newtonian Fluid Mechanics 166: 831-838.

138. Sridhar S (2002) Estimation models for molten slag and alloy viscosities. JOM 46-50.

139. Liu H, Qin $Y$, Yang $Y$, et al. (2018) Influence of $\mathrm{Al}_{2} \mathrm{O}_{3}$ content on the melting and fluidity of blast furnace type slag with low $\mathrm{TiO}_{2}$ content. Journal of Chemistry.

140. Mukherjee K, Prakash S (2013) On dependence of high temperature rheological behaviour of blast furnace slag on its network structure. 16th IFAC Symposium on Automation in Mining, Mineral and Metal Processing, 312-320.

141. Thakur MK, Sarkar C (2020) Influence of graphite flakes on the 
Citation: Okorie O (2020) High Temperature Rheological Characteristics of Iron and Steel Making Slag and its Waste Heat Recovery-A Review. Adv Metallurg Mater Eng 3(1):104-116

strength of magnet orheological fluids at high temperature and its rheology. IEEE Transactions on Magnetics 56.

142. Korolczuk-Hejnak M, Migas P (2012) Selected grades of steel as rheologically defined liquid bodies. Archives Of Metallurgy and Materials 57: 583-591.

143. Wang XH, Zhao DQ, He LB, et al. (2007) Modeling of a coalfired slagging combustor: Development of a slag submodel. Combustion and Flame 149: 249-260.

144. Wang P, Massoudi M (2011) Effect of coal properties and operation conditions on flow behavior of coal slag in entrained flow gasifiers: A brief review.

145. Kondratiev A, Hayes PC, Jak E (2006) Development of a quasi-chemical viscosity model for fully liquid slags in the $\mathrm{Al}_{2} \mathrm{O}_{3}$ $\mathrm{CaO}-\mathrm{FeO}-\mathrm{MgO}-\mathrm{SiO}_{2}$ system. Part 1 . Description of the model and its application to the $\mathrm{MgO}, \mathrm{MgO}-\mathrm{SiO}_{2}, \mathrm{Al}_{2} \mathrm{O}_{3}-\mathrm{MgO}$ and $\mathrm{CaO}$ MgO sub-systems. ISIJ International 46: 359-367.

146. Migas P (2015) High-temperatures rheometric analysis of selected heterogeneous slag systems. Archives of Metallurgy and Materials 60: 697-704.

147. Hu XJ, Ren ZS, Zhang GH, et al. (2012) A model for estimating the viscosity of blast furnace slags with optical basicity. International Journal of Minerals, Metallurgy, and Materials 19: 1088-1092.

148. Gasior W, Moser Z (2010) Modeling of Metals Viscosity - Comparative Analysis. Publishing House AKAPIT Cracow 47-55 (in Polish).

149. Seok SH, Jung SM, Lee YS, et al. (2007) Viscosity of highly basic slags. ISIJ International, 47: 1090-1096.

150. Song W, Tang L, Zhu X, et al. (2010) Flow properties and rheology of slag from coal gasification. Fuel 89: 1709-1715.

151. Jiang T, Liao D, Zhou M, et al. (2015) Rheological behavior and constitutive equations of heterogeneous titanium-bearing molten slag. International Journal of Minerals, Metallurgy, and Materials 22: 804-810.

152. Migas $P$, Slezak M (2015) High-temperature rheometry of blast furnace synthetic slags doped with $\mathrm{TiO}_{2}$ and TiN. Metallurgy and Foundry Engineering 41: 17-28.

153. Wang C, Zhang JL, Jiao KX, et al. (2017) Influence of CaF2 on the apparent viscosity of $\mathrm{CaO}-\mathrm{SiO} 2-\mathrm{MgO}-\mathrm{Al} 2 \mathrm{O} 3-\mathrm{TiO} 2$ slags. Metall Res Technol 114: 205.

154. Shen Y, Chong J, Huang Z, et al. (2019): Viscosity and structure of a $\mathrm{CaO}-\mathrm{SiO}_{2}-\mathrm{FeO}-\mathrm{MgO}$ system during a modified process from nickel slag by $\mathrm{CaO}$. Materials 12: 2562.

155. Yan Z, Reddy G.R, Lv X, et al. (2018) Structure-based viscosity model development for titania aluminosilicate slags. Ironmaking \& Steelmaking Journal 47: 203-209.

156. Chen H, Mao C, Weidong Z, et al. (2015) Viscosity Model for Iron Blast Furnace Slags in $\mathrm{SiO}_{2}-\mathrm{Al}_{2} \mathrm{O}_{3}-\mathrm{CaO}-\mathrm{MgO}$ System. Steel Research International 85: 678-685.

157. Chen H, Mao C, Weidong Z, et al. (2016) Evaluation of Existing Viscosity Data and Models and Developments of New Viscosity Model for Fully Liquid Slag in the $\mathrm{SiO}_{2}-\mathrm{Al}_{2} \mathrm{O}_{3}-\mathrm{CaO}-\mathrm{MgO}$ System. Metallurgical and Material Transactions B 47: 2861-2874.

158. Han C, Chen M, Zhang W, et al. (2015) Viscosity model for iron blast furnace slags in $\mathrm{SiO}_{2}-\mathrm{Al}_{2} \mathrm{O}_{3}-\mathrm{CaO}-\mathrm{MgO}$ system. Steel Research International.
159. Yamashita K, Sukenaga S, Matsuo M, et al. (2014) Rheological behavior and empirical model of simulated foaming slag. ISIJ International 54: 2064-2070.

160. Sohn I, Min DJ (2012) A review of the relationship between viscosity and the structure of calcium-silicate-based slags in ironmaking. Steel Research International 83: 611-630.

161. Zhang GH, Chou KC, Mills K (2012) Modelling viscosities of CaOMgO-Al2O3-SiO2 molten slags. ISIJ International 52: 355-362.

162. Xu JF, Zhang JY, Jie C, et al. (2011) Experimental measurements and modeling of viscosity in $\mathrm{CaO}-\mathrm{Al}_{2} \mathrm{O}_{3}-\mathrm{MgO}$ slag system. Ironmaking \& Steelmaking 38: 329-337.

163. Kim HS, Kim JG, Sasaki Y (2010) The role of molten slag in iron melting process for the direct contact carburization: Wetting and Separation. ISIJ International 50: 1099-1106.

164. Shu QF, Hu XJ, Yan BJ, et al. (2010) New method for viscosity estimation of slags in the $\mathrm{CaO}-\mathrm{FeO}-\mathrm{MgO}-\mathrm{MnO}^{-\mathrm{SiO}_{2}}$ system using optical basicity. Ironmaking Steelmaking 37: 387-391.

165. Tang XL, Guo M, Wang XD, et al. (2010) Estimation model of viscosity based on modified (NBO/T) ratio. Beijing Keji Daxue Xuebao 1542-1546.

166. Shu QA (2009) Viscosity estimation model for molten slags in $\mathrm{Al}_{2} \mathrm{O}_{3}-\mathrm{CaO}-\mathrm{MgO}-\mathrm{SiO}_{2}$ system. Steel Research International 80: 107-113.

167. Kalicka Z, Kawecka-Cebula E, Pytel K (2009) Application of the lida model for estimation of slag viscosity for $\mathrm{Al}_{2} \mathrm{O}_{3}-\mathrm{Cr}_{2} \mathrm{O}_{3}-\mathrm{CaO}$ $\mathrm{CaF}_{2}$ systems. Archives of Metallurgy Materials 54: 179-187.

168. Van Dyk JC, Waanders FB, Benson SA, et al. (2009) Viscosity predictions of the slag composition of gasified coal, utilizing FactSage equilibrium modeling. Fuel 88: 67-74.

169. Park S, Oh MS (2008) Slagging of petroleum coke ash using Korean anthracites. J Industrial Eng Chem 14: 350-356.

170. Nakamoto M, Lee J, Tanaka T (2005) A model for estimation of viscosity of molten silicate slag. ISIJ International 45: 651-656.

171. Buhre BJP, Browning GJ, Gupta RP, et al. (2005) Measurement of the Viscosity of Coal-Derived Slag Using Thermomechanical Analysis. Energy \& Fuels 19: 1078-1083.

172. Browning GJ, Bryant GW, Hurst HJ, et al. (2003) An Empirical Method for the Prediction of Coal Ash Slag Viscosity. Energy Fuels 17: 731-737.

173. Meng Y, Thomas BG (2003) Heat-transfer and solidification model of continuous slab casting: CON1D. Metallurgical Materials Trans B 34B: 685-705.

174. Reddy RG, Hebbar K (2001) Viscosity of FeO-SiO2. Minerals \& Metallurgical Processing 18: 195-199.

175. Mudersbach D, Drissen PM, Kuhn M, et al, (2001) Viscosity of slags. Steel Research 72: 86-90.

176. Shahbazian $F$ (2001) Experimental studies of the viscosities in the $\mathrm{CaO}-\mathrm{FeO}-\mathrm{SiO} 2-\mathrm{CaF} 2$ slags. Scandinavian J Metallurgy 30: 302-308.

177. Kondratiev A, Jak E (2001) Review of experimental data and modeling of the viscosities of liquid slags in the $\mathrm{Al}_{2} \mathrm{O}_{3}-\mathrm{CaO}-\mathrm{FeO}-$ $\mathrm{SiO}_{2}$ system. Metallurgical and Materials Transactions B 32: 1015-1025.

178. lida $T$, Sakai $H$, Kita $Y$, et al. (2000) An equation for accurate prediction of the viscosities of blast furnace type slags from chemical composition. ISIJ International 40: S110-S114. 
Citation: Okorie O (2020) High Temperature Rheological Characteristics of Iron and Steel Making Slag and its Waste Heat Recovery-A Review. Adv Metallurg Mater Eng 3(1):104-116

179. Mills KC, Sridhar S (1999) Viscosities of iron making and steelmaking slags. Ironmaking and Steelmaking 26: 262-268.

180. Urbain G (1987) Viscosities of Estimation of Slags. Steel Research 58: 111-116.

181. Watt JD, Fereday F (1969) The flow properties of slags formed from the ashes of British coals: Part 1. Viscosity of homogenous liquid slags in relation to slag composition. J. Institute of Fuel 42: 99-103.

182. Kato M, Minowa S (1969) Viscosity measurements of molten slag-properties of slag at elevated temperature (Part I). Trans ISIJ 9: 31-38.

183. Weymann HD, (1962) Temperature dependence of viscosity. Kolloid Z. Polymer 181: 131-137.

184. Suryavanshi R, Pitale AD (2017) A review on waste heat recovery in industries. International Journal of Research in Advent Technology 5: 32-35.

185. Lukin S, Shestakov N, Il'icheva E (2019) Heat exchange in the granulation chamber of an installation for slag dry granulation. Metallurgist 63: 804-812.

186. Cooksey M, Guiraud A, Kuan B, et al. (2019) Design and operation of dry slag granulation pilot Plant. Journal of Sustainable Metallurgy 5: 181-194.

187. Jouhara H, Khordehgah N, Almahmoud S, et al. (2018) Waste heat recovery technologies and applications. Thermal Science and Engineering Progress 6: 268-289.

188. Yu P, Wang S, Li Y, et al. (2016) A review of granulation process for blast furnace slag. MATEC Web of Conferences 68:1-4.

189. Ozturk Z, Gultekin E (2015) Preparation of ceramic wall tiling derived from blast furnace slag. Ceramics International 41: 12020-12026.

190. Peng Li, Qingbo Yu, Qin Qin, et al. (2011) The study of coal gasification in molten blast furnace slag. Energy Technology 77-84.

191. Chen C, Herbert G, Bouzidi Y, et al. (2010) LCA allocation procedure used as an incitative method for waste recycling: An Application to Mineral Additions in Concrete. Resources, Conservation and Recycling 54: 1231-1240.

192. Motz H, Geiseler J (2001) Products of steel slags and opportunity to save natural resources. Waste Management, 21: 285-293.

193. Yoshinaga M, Fujii K, Shigematsu T, et al. (1982) Dry granulation and solidification of molten blast furnace slag. Transactions of the Iron and Steel Institute of Japan 22: 823-829.

194. Bisio G (1997) Energy recovery from molten slag and exploitation of the recovered energy. Energy 22: 501-509.

195. Xie S, Li H (2015) Waste heat recovery technology of iron and steel enterprises. ICADME, 2060-2063.

196. Dhirhi R, Prasad K, Shukla AK (2016) Experimental study of rotating dry slag granulation unit: Operating regimes, particle size analysis and scale up. Appl. Therm. Eng 107: 898-906.

197. Rycroft M (2014) Heat recovery from slag improves energy efficiency of furnaces. Sustainable Energy 55-57.

198. Yao X, Yu Q, Xu G, et al. (2019) Thermodynamics of hydrogen production from steam reforming of tar model compound with blast furnace slag. IOP Conf. Series: Earth and Environmental Science 237: 1-6.

199. Sun YQ, Zhang ZT, Liu LL, et al. (2014a) Multi-Stage control of waste heat recovery from high temperature slags based on time temperature transformation curves. Energies 7: 16731684.

200. Tobo H, Shigaki N, Hagio Y (2014) Development of heat recovery system from steelmaking slag. JFE Technical Report 126132.

201. Cai JJ, Wang JJ, Chen CX, et al. (2007) Recovery of residual heat integrated steelworks. Iron Steel 42: 1-6.

202. Gan L, Shangguan F, Zhou J (2017) Simulation of Heat Transfer and Crystallization of Molten Blast Furnace Slag Droplets During Continuous Cooling. Heat Transfer Research 48: 361378.

203. Liu J, Yu Q, Peng J, et al. (2017) Waste heat recovery from high-temperature blast furnace slag particles. J Sci Ind Res 76: 187-192.

204. Zhang H, Wang H, Zhu X, et al. (2013) A review of waste heat recovery technologies towards molten slag in steel industry. Applied Energy 112: 956-966.

205. Maruoka N, Mizuochi T, Purwanto H, et al. (2004) Feasibility study for recovering waste heat in the steelmaking industry using a chemical recuperator. ISIJ Int 44: 257-262.

206. Hasali Y (2019) Criteria for chemical equilibrium with application to methane steam reforming. Int. J. Hydrog. Ener 44: 5766-5772.

207. Cahyono RB, Alya NailiRozhan, NaotoYasuda, et al. (2013) Integrated coal-pyrolysis tar reforming using steelmaking slag for carbon composite and hydrogen production. Fuel 109: 439444.

208. Peng Li, Qingbo Yu, Qin Qin, et al. (2012) Kinetics of $\mathrm{CO}_{2} /$ Coal gasification in molten blast furnace slag. Ind Eng Chem Res 51: 15872-15883.

209. .Peng Li, Qingbo Yu, Huaqing Xie, et al. (2013) $\mathrm{CO}_{2}$ gasification rate analysis of Datong coal using slag granules as heat carrier for heat recovery from blast furnace slag by using a chemical reaction. Energy Fuels 27: 4810-4817.

210. Luo S, Zhou Y, Yi C (2012) Hydrogen-rich gas production from biomass catalytic gasification using hot blast furnace slag as heat carrier and catalyst in moving-bed reactor. Int J Hydrog Energy 37: 15081-15085.

211. Kasai E, Kitajima T, Akiyama T, et al. (1997) Rate of methane-steam reforming reaction on the surface of molten $B F$ slag-for heat recovery from molten slag by using a chemical reaction. ISIJ International 37: 1031-1036.

212. Shimada T, Akiyama T, Kasai E, et al. (2000) Observation of molten slag surface under gas impingement by $\mathrm{x}$-ray computed tomography. ISIJ Int 40: 958-963.

213. Shimada $T$, Kochura V, Akiyama T, et al. (2001) Effects of slag compositions on the rate of methane-steam reaction. ISIJ Int 41: 111-115.

214. Mizuochi T, Akiyama T, Shimada T, et al. (2001) Feasibility of rotary cup atomizer for slag granulation. ISIJ Int 41: 1423-1428.

215. Purwanto $\mathrm{H}$, Akiyama $\mathrm{T}$ (2006) Hydrogen production from biogas using hot slag. Int J Hydrog Energy 31: 491-495.

216. Nomura T, Okinaka N, Akiyama T (2010) Technology of latent heat storage for high temperature application: A review. ISIJ Int 50: 1229-1239. 
217. Shimizu T, Haga D, Mikami G (2010) Heat recovery from melted blast furnace slag using fluidized bed. The 13th International Conference on Fluidization - New Paradigm in Fluidization Engineering Art 83: 1-6.

218. Moon JW, Kim HS, Sasaki Y (2010) Energy recuperation from slags. In: Proceedings of the first international slag valorisation symposium. Leuven, Belgium, Katholieke Universiteit Leuven, Belgium, 143-150.

219. Zhao L, Wang H, Qing S, et al. (2010) Characteristics of gaseous product from municipal solid waste gasification with hot blast furnace slag. J. Nat. Gas Chem. 19: 403-408.

220. Chan D, Yang K, Lee JD, et al. (2010) The Case Study of Furnace use and Energy Conservation in Iron and Steel Industry. Energy 35: 1665-1670.

221. Luo S, Yi C, Zhou Y (2013) Bio-oil production by pyrolysis of biomass using hot blast furnace slag. Renew Energy 50: 373-377.

222. Duan WJ, Yu QB, Xie HQ, et al. (2014) Thermodynamic analysis of hydrogen-rich gas generation from coal/steam gasification using blast furnace slag as heat carrier. International Journal of Hydrogen Energy 39: 11611-11619.

223. Duan WJ, Yu QB, Wang K, et al. (2015) SPEN Plus simulation of coal integrated gasification combined blast furnace slag waste heat recovery system. Energ Convers Manage 100: 30-36.

224. Motz H, Ehrenberg A, Mudersbach D (2015) Dry solidification with heat recovery of ferrous slag. Mineral Processing and Extractive Metallurgy 124: 67-75.

225. Shachit SI, Renganathan T, Pushpavanam S, et al. (2015) Generalised thermodynamic analysis of methanol synthesis: Effect of feed composition. Journal of $\mathrm{CO}_{2}$ Utilization 10: 95-104.
226. Liu J, Yu Q, Peng J, et al. (2015) Thermal energy recovery from high-temperature blast furnace slag particles. International Communications in Heat and Mass Transfer 69: 23-28.

227. Deng L, Tang C, Tan X, et al. (2017) A Study on Air-Cooling Waste Heat Recovery From Molten Slag of Slag-Tap Boilers. Sage Journal.

228. Renuka S (2017) Application of phase change materials in heat recovery from blast furnace slag. SSRG International Journal of Mechanical Engineering 4: 19-22.

229. Li P (2017) Thermodynamic analysis of waste heat recovery of molten blast furnace slag. International Journal of Hydrogen Energy 42: 9688-9695.

230. Zhan Y, Duan $W, Y u$ Q, et al. (2018) Numerical simulation and optimization of slag bath coal gasification reaction. IEEA: Proceedings of $7^{\text {th }}$ International conference on informatics, environment, energy and applications. 119-123.

231. Duan W, Yu Q, Wang Z, et al. (2018) Life cycle and economic assessment of multi-stage blast furnace slag waste heat recovery system. Energy Elsevier 142: 486-495.

232. Sun $Y$, Chen J, Zhang $Z$ (2019a) Biomass gasification using the waste heat from high temperature slags in a mixture of $\mathrm{CO}_{2}$ and $\mathrm{H}_{2} \mathrm{O}$. Energy 167: 688-697.

233. Zhang Y (2019) Recovery and utilization of metallurgical solid waste. In tech Open, London.

234. Wu Z, Ma C, Zhang B, et al. (2020) Energy recovery of furnace slag from steel industrial and thermochemical conversion of lignocellulosic biomass: Thermal behavior and kinetic analysis on cellulose under fast pyrolysis conditions. Energy Fuels 34: 1111-1118. 